University of Nebraska - Lincoln

DigitalCommons@University of Nebraska - Lincoln

U.S. National Park Service Publications and

Papers

National Park Service

1994

Restoration of Woodland Caribou to the Lake Superior Region

Peter J. P. Gogan

Yellowstone National Park

Jean Fitts Cochrane

USFWS, Anchorage, AL

Follow this and additional works at: https://digitalcommons.unl.edu/natlpark

Part of the Environmental Sciences Commons

Gogan, Peter J. P. and Cochrane, Jean Fitts, "Restoration of Woodland Caribou to the Lake Superior Region" (1994). U.S. National Park Service Publications and Papers. 11.

https://digitalcommons.unl.edu/natlpark/11

This Article is brought to you for free and open access by the National Park Service at DigitalCommons@University of Nebraska - Lincoln. It has been accepted for inclusion in U.S. National Park Service Publications and Papers by an authorized administrator of DigitalCommons@University of Nebraska - Lincoln. 
9

\title{
Restoration of woodland caribou to the Lake Superior region
}

\author{
PETER J. P. GOGAN AND \\ JEAN FITTS COCHRANE
}

\begin{abstract}
Introduction
Woodland caribou (Rangifer tarandus caribou) historically occupied the boreal forest zone across the North American continent. The distribution and abundance of the species has declined in the past century. In particular, it has been extirpated from much of the southern limits of its historical range on both sides of the boundary between Canada and the United States (Bergerud 1974). Translocation of animals from extant populations may be used to reestablish populations in portions of the species' former range. Recently, wildlife biologists in Ontario have translocated woodland caribou to a number of sites in or adjacent to Lake Superior. While it is too soon to evaluate their long-term success, these restoration efforts do provide useful insights into factors likely to influence the outcome of woodland caribou translocations elsewhere. In this chapter, we examine the 1) historical changes in range distribution, 2) natural history characteristics and requirements, and 3) results of recent translocations of woodland caribou, and use them to evaluate several alternative sites for possible woodland caribou restoration in the Lake Superior region. We also apply minimum viable population analysis to evaluate several translocation scenarios.
\end{abstract}

\section{Distribution of woodland caribou}

The woodland caribou's distribution and abundance along the southern edge of its range declined dramatically in the late 1800s and early 1900s (Bergerud 1974). In the Lake Superior region, woodland caribou were extirpated from the mainland of Michigan in 1912 (Baker 1983) and from Isle Royale in 1928. They disappeared from Minnesota in the 1940s (Fashingbauer 1965), but there were sporadic sightings of at least two woodland caribou in extreme northeastern Minnesota during the winter of 1981-82 (Peterson 1981, Mech, Nelson \& Drabik 1982). 


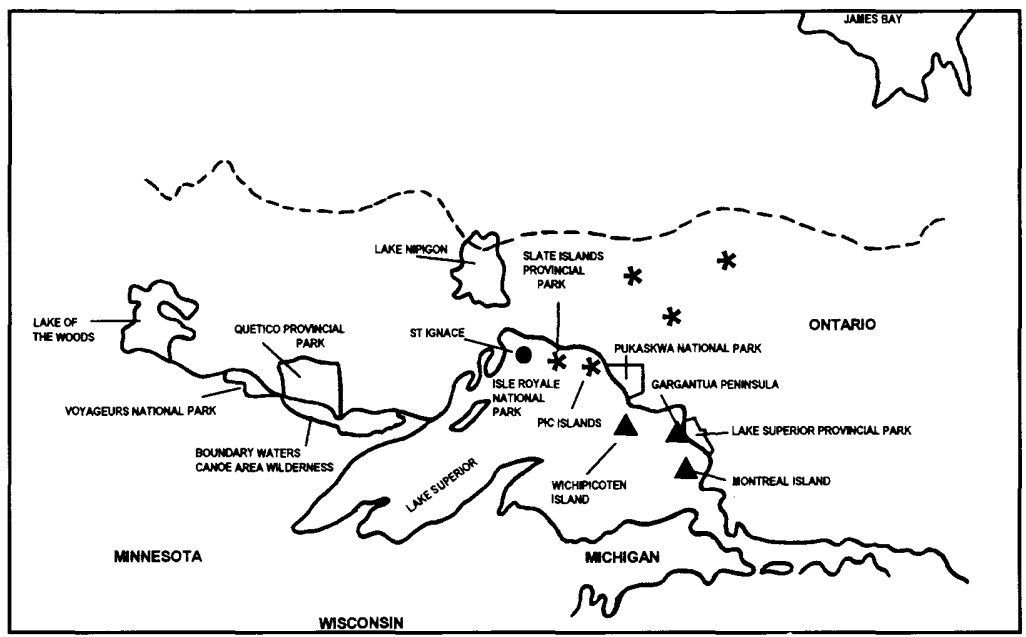

Fig. 9.1. Location of woodland caribou remnant herds (asterisks), successful reintroductions (triangles), and a failed reintroduction (circle), and sites being evaluated for restoration of the species in the Lake Superior region. Dashed line represents the southern limit of continuous distribution.

In Ontario, woodland caribou retracted gradually northward from Lake Superior between 1900 and 1950 (Cringan 1957), and disappeared from the western shore between 1905 and 1912 (Riis 1938a, b, c, d) (Fig. 9.1). In the Lake Nipigon area, where they were once the only cervid, they became uncommon soon after the Canadian National Railway was constructed across the north end of the lake around 1910 (Dymond, Snyder \& Logier 1928). They were declining and scarce on the Sibley Peninsula by 1914 (Cringan 1957). Farther east, woodland caribou range was still continuous south to Lake Superior in 1950, and, possibly as late as the 1960s, to what is now Pukaskwa National Park (Bergerud 1989).

The decline in numbers and continued northward shift in distribution of woodland caribou in the Lake Superior region parallels a continent-wide trend that has prompted British Columbia (Stevenson \& Hatler 1985), Alberta (Edmonds 1986, 1988, Edmonds \& Bloomfield 1984), Manitoba (Shoesmith 1986) and Ontario (Darby et al. 1989) to review the species' status. Populations have been restored to portions of Quebec (Bonefant 1974) and Newfoundland (Bergerud \& Mercer 1989), and a remnant population along the border between British Columbia and Idaho has been reinforced (Servheen 1988, 1989). A reintroduction to Maine in 1989 and 1990 failed (McCollough \& Connery 1991), perhaps because of black bear predation.

Hypotheses proposed for the decline in the distribution and abundance of woodland caribou include 1) logging and catastrophic fire have destroyed 
habitat, 2) hunting has increased, 3) predation has increased, partly because gray wolf (Canis lupus) density has increased in response to an increase in other prey species, such as moose (Alces alces) and white-tailed deer (Odocoileus virginianus), 4) woodland caribou have contracted meningeal brainworm (Parelaphostrongylus tenuis) from white-tailed deer as the deer expanded their range north and colonized the early-successional forests resulting from catastrophic fires and logging, and 5) a combination of these factors (Bergerud 1974).

The current southern boundary of continuous woodland caribou distribution crosses Ontario at about 50 degrees latitude (Darby et al. 1989, Abraham et al. 1990). This line bisects the boreal coniferous forest, and moose and wolves decline to its north (Darby et al. 1989, Bergerud 1989). Darby et al. (1989) list only six native herds of woodland caribou remaining south of $50^{\circ}$ latitude, in 1) Slate Islands Provincial Park, 2) Pic Island and Neys Provincial Park, and 3) Pukaskwa National Park, all on Lake Superior, and 4) three inland bands (Fig. 9.1). Gene flow between these herds is limited to the occasional wandering of young bulls (Bergerud 1989). In 1990, there were approximately 500 woodland caribou in the six herds. About 100 of them were on the Slate Islands (Abraham et al. 1990); this herd had declined from an estimated 600 to 100 during the winter of 1989-90 (A.T. Bergerud, personal communication). All of these relict populations are tenuous, because they are small and isolated, there are high wolf densities in adjacent areas, and predicted global warming trends would allow white-tailed deer to expand their range (Bergerud 1989).

\section{Natural history characteristics and requirements}

\section{Habitat use}

Woodland caribou may select habitat to avoid predators, by avoiding habitat preferred by predators (Bergerud \& Page 1987, Jakimchuk, Ferguson \& Sopuck 1987), avoiding habitat used by alternate prey and hence potentially having greater predator densities (Bergerud \& Page 1987), and selecting good escape habitat regardless of predator densities (Bergerud 1989). These patterns apply especially in spring and summer, when woodland caribou are most vulnerable. Within the constraint of avoiding predators, they select sites with optimal forage resources or to escape deep snow or biting insects (Bergerud, Ferguson \& Butter 1990). Schaefer \& Pruitt (1991), however, conclude that woodland caribou select habitats primarily for optimal forage, and secondarily for suitable snow conditions in winter.

While woodland caribou are generally associated with mature, northern 
boreal forests, they will exploit young deciduous forests where predation risks are low. For example, woodland caribou on the Slate Islands and the islands in Lake Nipigon use early- to mid-successional mixed deciduous forests as much as or more than they use mature coniferous forest (Euler, Snyder \& Timmermann 1976, Bergerud et al 1990). Woodland caribou in southeast Manitoba also use mixed deciduous forest, but less than they use mature coniferous forest (Darby \& Pruitt 1984).

Woodland caribou in their typical boreal forest habitat migrate short distances or not at all, and remain widely dispersed from each other for most of the year (Fuller \& Keith 1981, Shoesmith \& Storey 1977, Cumming \& Beange 1987, Edmonds 1988, Darby \& Pruitt 1984, Bergerud 1989, Bergerud et al. 1990); this spacing minimizes contact with predators (Bergerud 1983, Bergerud et al. 1990). Bergerud (1980) calculated that in boreal forests woodland caribou typically need $2.6 \mathrm{~km}^{2}$ per animal to minimize contacts with predators (to 'space out'), but only $0.25 \mathrm{~km}^{2}$ per animal to find adequate food supplies (see also Bergerud et al. 1990).

Some observers consider lichens to be highly important to woodland caribou diet and range selection (Bergerud 1972, 1974, Euler et al. 1976). Caribou confined to the taiga biome of northern Canada in winter are restricted to a diet of lichens (Skoog 1968); however, remnant and translocated woodland caribou herds persist on Lake Superior islands where ground lichens are browsed out (Slate Islands, Pic Island) (Euler et al. 1976; Bergerud 1983; Ferguson, Bergerud \& Ferguson 1988) or on which there is deciduous forest with few lichens (Michipicoten Island) (G. Eason, personal communication).

The relationship between woodland caribou, ground lichen abundance, and fire is poorly understood. Cladina lichen stands in jack pine (Pinus banksiana) and black spruce (Picea mariana) forests are fire-dependent, but fire temporarily reduces their abundance (Abraham et al. 1990). In one case, woodland caribou used burned taiga habitats in southern Manitoba less about five years after a forest fire, as deadfalls increased and remnant lichen stands decreased (Schaefer \& Pruitt 1991). Ground lichen biomass peaks 40-100 years post-fire, when the tree canopy is relatively open (Bergerud 1978, Abraham et al. 1990), but snow conditions improve for woodland caribou as the forest canopy closes and reduces the depth of snow on the ground (Schaefer \& Pruitt 1991).

Woodland caribou shift between seasonal ranges to avoid predators, deep snow, and biting insects, and to find food (Shoesmith \& Storey 1977, Fuller \& Keith 1981, Darby \& Pruitt 1984, Edmonds \& Bloomfield 1984, Cumming \& Beange 1987, Bergerud et al. 1990). Typically, woodland caribou move from isolated calving and summering habitat on islands and adjacent shores, or in 
remote bogs, to gather in fall rutting habitat, also on islands or open bogs. They remain in the rutting habitat until snow depth exceeds $50 \mathrm{~cm}$, then switch to more exposed ridges or jack pine habitat (Abraham et al. 1990). Bergerud (1989, A. T. Bergerud, personal communication) hypothesized that they select open habitats primarily because they can more easily detect or escape predators, and secondarily because they can survive on the plants of open habitats (bog shrubs and sedges, and ground lichens). Forested habitats provide relief from biting insects and coincide with prime escape habitat in open areas and along shorelines (Bergerud et al. 1990).

\section{Home range and density}

The home ranges of individual woodland caribou vary from $13 \mathrm{~km}^{2}$ in summer, when the herds are most dispersed, to $335 \mathrm{~km}^{2}$ in winter (Shoesmith \& Storey 1977, Fuller \& Keith 1981, Darby \& Pruitt 1984). The ranges of entire herds have been calculated as $95-140 \mathrm{~km}^{2}$ in winter and $175-190 \mathrm{~km}^{2}$ in summer in southern Manitoba (Darby \& Pruitt 1984), and $390 \mathrm{~km}^{2}$ in winter near Lake Nipigon, Ontario (Cumming \& Beange 1987).

Bergerud (1983, p. 48) calculated an average mainland woodland caribou herd's density to be 0.4 per $\mathrm{km}^{2}$, using a 'synthesis of boreal populations, frequently in joint equilibrium with self-sustaining wolf populations (two to four wolves per $1000 \mathrm{~km}^{2}$ )'. Bergerud (personal communication) would now revise this woodland caribou density estimate to 0.3 per $\mathrm{km}^{2}$. Where moose are also present and wolf densities are higher (7-15 per $\left.1000 \mathrm{~km}^{2}\right)$, woodland caribou herd densities are typically lower (less than 0.2 per $\mathrm{km}^{2}$ ) (Bergerud 1983). Densities of the remnant population at Pukaskwa National Park have varied from 0.05 to 0.12 per $\mathrm{km}^{2}$ (Bergerud 1980). Densities across Ontario vary from 0.006 to 0.05 per $\mathrm{km}^{2}$ in areas ranging from 4300 to $293000 \mathrm{~km}^{2}$, not all of which is occupied by woodland caribou (Ontario Ministry of Natural Resources 1986, Darby et al. 1989, Cumming \& Beange 1987, Bergerud et al. 1990). Thus, much of the variation in density estimates reflects differences in the resolution of the censuses, which is affected by region, study area, occupied polygons, subsets of prime habitat, and seasonal ranges. For example, the density of the Lake Nipigon woodland caribou herd has been reported as 0.006 per $\mathrm{km}^{2}$ for a $32000 \mathrm{~km}^{2}$ study area, 0.07 per $\mathrm{km}^{2}$ for the area that the woodland caribou actually used, and 1.8 per $\mathrm{km}^{2}$ for small islands in summer (Cumming \& Beange 1987), and as 0.05 per $\mathrm{km}^{2}$ for an area that included the waters of Lake Nipigon (Bergerud et al. 1990).

Woodland caribou densities on islands are generally higher than on the mainland (A.T. Bergerud, personal communication). On the predator-free Slate 
Islands, woodland caribou densities have fluctuated between 4 and 17 per $\mathrm{km}^{2}$ for many decades (Bergerud 1980, A.T. Bergerud, personal communication). Populations of woodland caribou on the Slate Islands and on Pic Island, at densities ranging between 2 and 5 per $\mathrm{km}^{2}$, continue to be highly productive despite food shortages (Bergerud 1983; Ferguson et al. 1988; A.T. Bergerud, personal communication). In general, however, food resource depletion is apparent by the time woodland caribou densities reach 5 per $\mathrm{km}^{2}$ (Bergerud 1980). Peak densities on the Slate Islands have been followed by die-offs and no reproductive success in following years (A.T. Bergerud, personal communication). Overgrazing is evident on islands in Lake Nipigon, at a current average summer density of 1.8 per km² (Cumming \& Beange 1987, Bergerud et al. 1990).

\section{Predators}

Woodland caribou protect themselves from predators by avoiding detection ('hiding in space' or dispersing), running, or using escape features such as water and steep cliffs, and the cows do not defend their young against predators (Bergerud 1980, 1985; Bergerud, Butler \& Miller 1984; Bergerud \& Page 1987; Cumming \& Beange 1987; Ferguson et al. 1988; Bergerud et al. 1990). Islands are frequented in summer, and the few that do not freeze in (e.g. Slate Islands and Pic Islands) provide year-round refugia (Simkin 1965, Bergerud 1974, Shoesmith \& Storey 1977, Cumming \& Beange 1987, Ferguson et al. 1988, Bergerud 1989, Bergerud et al. 1990) by separating woodland caribou from mainland predators and offering water escape.

Woodland caribou will continue to seek refuge on islands when forage is greatly depleted, even if abundant forage is available nearby on the mainland (Ferguson et al. 1988, Bergerud et al. 1990). Bergerud et al. (1990) found that at Lake Nipigon, migration is timed according to ice development and melt, not insect or vegetation cycles. Woodland caribou use the shoreline as escape habitat, and remain within $100 \mathrm{~m}$ of shore at Lake Nipigon, Pic Island, Pukaskwa National Park, and Reed Lake, Manitoba (Shoesmith \& Storey 1977, Bergerud 1984, Cumming \& Beange 1987, Ferguson et al. 1988, Bergerud 1988, Bergerud et al. 1990).

Predation has been proposed as the most consistent regulator of woodland caribou populations in the boreal forest (Bergerud 1983). Many mainland North American woodland caribou populations have declined in areas that have moose and high wolf densities (7-15 wolves per $1000 \mathrm{~km}^{2}$ ) (Bergerud 1983). Bergerud \& Elliot (1986, p. 1525) reviewed woodland caribou population dynamics in numerous North American herds and concluded that 
'caribou cannot coexist (with wolves) away from refuge habitat when moose biomass allows wolf numbers to increase to high levels (more than 6.5 per $\left.1000 \mathrm{~km}^{2}\right)^{\prime}$.

Relict herds of woodland caribou persist in the face of high wolf densities only where excellent escape habitat is available for young calves (Bergerud 1980 , 1984). For instance, woodland caribou presently survive at Lake Nipigon, where wolf densities are commonly $10-14$ per $1000 \mathrm{~km}^{2}$, by calving and summering on islands inaccessible to wolves in summer (Cumming \& Beange 1987, Bergerud et al. 1990). The small band of woodland caribou at Pukaskwa National Park, where wolf densities average 13-14 per $1000 \mathrm{~km}^{2}$, follows a similar strategy (Bergerud 1989).

Although a number of woodland caribou reintroductions to sites in Newfoundland where black bears (Ursus americanus) are potential predators have been successful (Bergerud \& Mercer 1989), predation by black bears was an important cause of mortality in woodland caribou released in northern Maine in 1989 and 1990 (McCollough \& Connery 1991).

\section{Parasites and diseases}

White-tailed deer are the normal definitive host and terrestrial gastropod snails are the intermediate host for the meningeal brainworm. Meningeal brainworm may become prevalent in white-tailed deer even where there is a low incidence of larvae in the intermediate host (Nudds 1990). Infection of woodland caribou with this parasite is generally fatal (Anderson \& Strelive 1968, Anderson 1971). In areas occupied by white-tailed deer where woodland caribou reintroductions have failed, it has been confirmed or suspected that the woodland caribou were infected with meningeal brainworm (Bergerud \& Mercer 1989). Although specific documentation of the mortality of woodland caribou translocated to white-tailed deer ranges is frequently lacking (see Nudds 1990), three of four sites in Minnesota that had appropriate habitat for the release of woodland caribou were rejected because they had a high risk of meningeal brainworm infection (Karns 1980).

In Newfoundland, where reindeer have been introduced, free-ranging woodland caribou have been infected with a Eurasian reindeer parasite, Elaphostrongylus cervi rangiferi. Moose experimentally infected with E. cervi developed pathological changes and paralysis (Lankester 1976). Moose in northeastern Minnesota may have been exposed to this parasite when European reindeer were stocked in Superior National Forest in the 1910s to 1930s (Aldous 1931, R.C. Anderson, personal communication). An E. cervilike parasite was tentatively identified in woodland caribou in Ontario 
(Lankester 1976, Lankester \& Northcott 1979, Gray \& Samuel 1986), but it has now been positively identified as a muscle worm (Parelaphostrongylus andersoni) (Lankester \& Hauta 1989) common in white-tailed deer across North America (Anderson \& Prestwood 1981, Pybus \& Samuel 1984) and woodland caribou in Labrador and Ontario (Lankester \& Hauta 1989). It apparently is not detrimental to either species, but its impact on moose is unknown. The impact of the transmission of $P$. andersoni to the isolated population of moose if woodland caribou are restored to Isle Royale is potentially serious, especially since the moose are already heavily infested with both hydatid tapeworms (Echinococcus granulosus) and winter ticks (Dermacentor albipictus) (R. O. Peterson, personal communication).

\section{Population dynamics}

Compared with other cervids, woodland caribou have a low reproductive rate, because they mature slowly and have single births. Typically, female caribou become sexually mature at 2.5 years, although a few breed as yearlings and some do not breed until 3.5 years or older (Bergerud 1974, 1978, 1980). Pregnancy rates average $84 \%$ for females 2.5 years or older (Bergerud 1980), and $96 \%$ for females 3.5 years or older (R. Page, personal communication). These rates are very consistent within herds from year to year; the proportion of non-parous two-year-olds accounts for annual variation in population productivity (Bergerud 1980, R. Page, personal communication).

Although sex ratios at birth typically favor males (Bergerud 1980, 1983), the adult ratio of males to females averages 39:61 (Bergerud 1980). Males suffer higher mortality from at least four years old, and in some populations from birth (Bergerud 1971, 1980, 1989, Thomas, Barry \& Kiliaan 1989). Female woodland caribou may live to 17 years, and males may live to 13 years (Bergerud 1980). Because of the preponderance of females among adults, when the calves are newborn, they comprise $27-30 \%$ of the population (Bergerud 1980). In an average year, only $20 \%$ of mature bulls breed, each siring six to eight calves (R. Page, personal communication). However, dominance is associated with stress and high mortality rates, and the turnover of dominant males is high; they rarely live through the winter of their fifth or sixth year (R. Page, personal communication).

In the first year, woodland caribou calf mortality averages $50 \%$ and sometimes reaches 80 or $90 \%$ (Bergerud 1980, 1983, Bergerud \& Page 1987). Without predation, annual adult mortality averages 5 or $6 \%$. With predation, annual adult mortality averages $10 \%$ ( $7 \%$ for females, $13 \%$ for males) (Bergerud 1983); in declining populations it can be as high as 20 or $30 \%$ 
(Bergerud 1989, A. T. Bergerud, personal communication). Thus, calf recruitment (to one year) averages $10-15 \%$ in stable populations (Bergerud 1980, 1983, R. Page, personal communication). Under ideal conditions (e.g. release onto predator-free islands) caribou populations grow at an intrinsic rate of $30-35 \%$ per year (Bergerud 1980). Observed population growth rates in mainland herds averaged $28 \%$ per year without wolf predation, and $2 \%$ per year with 'normal' wolf densities (four wolves per $1000 \mathrm{~km}^{2}$ ) (Bergerud 1980).

\section{Restorations and translocations in the Lake Superior region}

Since 1982, the Ontario Ministry of Natural Resources has restored or introduced woodland caribou from the Slate Islands to a number of islands and the shoreline of eastern Lake Superior, with varying success (Table 9.1, Fig. 9.1) (G. Eason, personal communication). All island release sites are free of both white-tailed deer and large predators.

In 1982, eight woodland caribou were moved to Michipicoten Island (Table 9.1), a provincial park $15 \mathrm{~km}$ from the north shore of Lake Superior. A single adult male, presumably from the Pukaskwa herd, was already on the island.

In 1984, efforts to restore woodland caribou to the offshore islands of Lake Superior Provincial Park began. Of nine animals reintroduced to Montreal Island (Table 9.1), two adult females dispersed and were replaced with two additional adult females. In 1986, three woodland caribou were moved from the Slate Islands to Leach Island, joining one of the females that had dispersed from the 1984 Montreal Island reintroduction (Table 9.1).

To date, the most ambitious effort to establish woodland caribou along the Lake Superior shoreline was in October 1989, in the Gargantua Peninsula area of Lake Superior Provincial Park (G. Eason, personal communication). The mainland has high winter densities of moose (more than 1 per $\mathrm{km}^{2}$ ), and white-tailed deer are occasionally sighted. Black bears are common, but their precise densities are unknown. Wolves are common, but they apparently avoid the Gargantua Peninsula area in most winters because of deep snow. Thirtynine woodland caribou, 17 with radio collars, were translocated to the Gargantua Peninsula and two small islands, which are $0.5 \mathrm{~km}$ and $1 \mathrm{~km}$ off shore.

The fate of this translocation is still uncertain (G. Eason, personal communication), but another attempt to restore woodland caribou to the north shore of Lake Superior failed, possibly because of wolf predation. Of six woodland caribou translocated to a small island adjacent to St. Ignace Island in October 
Table 9.1. Fate of recent translocation of woodland caribou in the Lake Superior region

\begin{tabular}{|c|c|c|c|c|c|c|c|c|}
\hline \multirow[b]{3}{*}{ Site } & \multirow{3}{*}{$\begin{array}{c}\text { Size } \\
\left(\mathrm{km}^{2}\right)\end{array}$} & \multirow{3}{*}{$\begin{array}{l}\text { Year of } \\
\text { trans- } \\
\text { location }\end{array}$} & \multicolumn{4}{|c|}{ Number of animals } & \multirow{2}{*}{\multicolumn{2}{|c|}{ Last census }} \\
\hline & & & \multicolumn{2}{|c|}{ male } & \multicolumn{2}{|c|}{ female } & & \\
\hline & & & adult & calf & adult & calf & year & number \\
\hline Michipicoten Is. & 183 & 1982 & 1 & - & 4 & 3 & 1988 & 26 \\
\hline Montreal Is. & 7 & 1984 & 1 & 3 & 1 & 1 & 1989 & 14 \\
\hline Leach Is. & 5 & 1986 & 1 & - & 1 & 1 & 1990 & $4^{a}$ \\
\hline $\begin{array}{l}\text { Gargantua } \\
\text { Peninsula }\end{array}$ & - & 1989 & 10 & 1 & 26 & 2 & - & - \\
\hline
\end{tabular}

Note: aPossibly all female.

Source: after G. Eason, personal communication.

1985, only one was thought to be alive by early April 1986 (Bergerud \& Mercer 1989).

\section{Planning for restorations}

\section{Administrative setting}

Any translocation of woodland caribou in the Lake Superior region would likely involve United States and Canadian federal agencies, including the Canadian Park Service and the United States Departments of Agriculture (USDA) and Interior (USDI), as well as provincial and state agencies, including the Ontario Ministry of Natural Resources (OMNR) and the Michigan or Minnesota Department of Natural Resources (MDNR). All existing woodland caribou herds in Ontario are under the administrative authority of OMNR, except the herd at Pukaskwa National Park, which is under the Canadian Park Service.

The OMNR has not as yet developed a provincial policy on the woodland caribou (Darby et al. 1989), but it has identified the herd at the Slate Islands as the source stock for restorations in northwestern Ontario. The Manitoba Ministry of Natural Resources (MMNR) has agreed to provide a limited number of adult males to any restoration, to reduce the probability of inbreeding depression. Furthermore, the management plan for Quetico Provincial Park states that native species such as woodland caribou may be restored to the park (Ontario Ministry of Natural Resources 1988). OMNR has stipulated that it 
will only consider requests for woodland caribou for restorations outside the province from government (not private) organizations with an approved restoration plan.

If woodland caribou are translocated from Canada to the United States, the complexity and the number of administrative agencies involved will increase. First, all animals, regardless of their destination, would have to be approved by the Animal and Plant Health Inspection Service of the USDA and the Department of Agriculture of the state receiving the animals. Furthermore, the Minnesota DNR has stipulated that it be the agency initiating any request to any Canadian provincial or federal agency to transfer woodland caribou to Minnesota. Some of the potential restoration sites, like the Superior National Forest (which includes the Boundary Waters Canoe Area Wilderness [BWCAW]), would also be under the authority of the USDA Forest Service (FS). Similarly, woodland caribou restored to Voyageurs National Park would be under the concurrent authority of the MDNR and the USDI National Park Service (NPS). At both sites, federal policies and regulations take precedence over those of the state.

Once reestablished, woodland caribou translocated to the United States could be listed as threatened or endangered under the United States Endangered Species Act of 1973, as amended, in which case management authority would revert to the USDI Fish and Wildlife Service.

In addition to state, provincial, and federal governments, the North Central Caribou Corporation (NCCC), a private nonprofit organization established in 1988, would play a key role in restoring woodland caribou to the western Lake Superior region. The NCCC, dedicated to the restoration of woodland caribou to the border of the central United States and Canada, is composed of five members of the Duluth Safari Club (not affiliated in any way with Safari Club International) and six biologists, representing the NPS, the FS, the MDNR, the OMNR (2 members), and the MMNR. The NCCC has created a technical advisory committee with members from federal and state agencies, the academic community, the Minnesota Zoo, and Friends of the BWCAW, and funded studies of the feasibility of woodland caribou restorations in the Lake Superior region, often with matching funds from the federal agencies and the university. Although the NCCC has no administrative authority, it is an example of how state and federal agencies and private organizations can work cooperatively and effectively toward restoration. 


\section{Evaluating the feasibility of restoration}

The North Central Caribou Corporation developed an assessment methodology to identify the factors necessary for successful restoration of woodland caribou (Fig. 9.2). These factors can be broken down into two broad categories.

First, woodland caribou demographics and genetics were used to develop guidelines for estimating the number of woodland caribou the potential restoration sites could possibly support at carrying capacity, the number and schedule of woodland caribou releases that would establish the populations, and the estimated probability of survival of the restored populations over particular time intervals. Population Vulnerability Analysis (Gilpin \& Soulé 1986) and a Monte Carlo model were used to estimate population extinction probabilities (VORTEX, Lacy 1991).

Second, the potential restoration sites were evaluated according to woodland caribou natural history requirements, including 1) the extent and quality of yearround habitat, 2) the types and abundances of potential caribou predators, especially gray wolves and black bears, and 3) the potential for transmission of the meningeal brainworm parasite from white-tailed deer to woodland caribou, and of other parasites from woodland caribou to moose or white-tailed deer.

\section{Population Vulnerability Analysis}

Population Vulnerability Analysis is the process of estimating minimum viable population (MVP) sizes for specific populations (Gilpin \& Soulé 1986). An MVP is the threshold number of organisms that ensures, at some defined level of risk, that a population will persist for a given time interval at a particular location. Conventional standards for MVP's include 1) greater than $90 \%$ certainty of long-term (usually centuries) persistence, 2 ) population maintenance in nature with no significant demographic or genetic manipulation, and 3) retention of replacement levels of immediate fitness (vigor, fertility, fecundity) and sufficient genetic variation to adapt by natural selection to changing environments (Soulé 1987). Based upon the last criterion, Lande \& Barrowclough (1987) suggested that at least several hundred individuals are necessary for an MVP to be established.

Not all potential release sites will be large enough to support several hundred individuals at carrying capacity. For instance, based upon the range of woodland caribou densities reported in Ontario, Isle Royale National Park could support at most 54 animals. In such cases, it may be necessary to manage several small populations as a single metapopulation (see also Lacy, Chapter 3, 


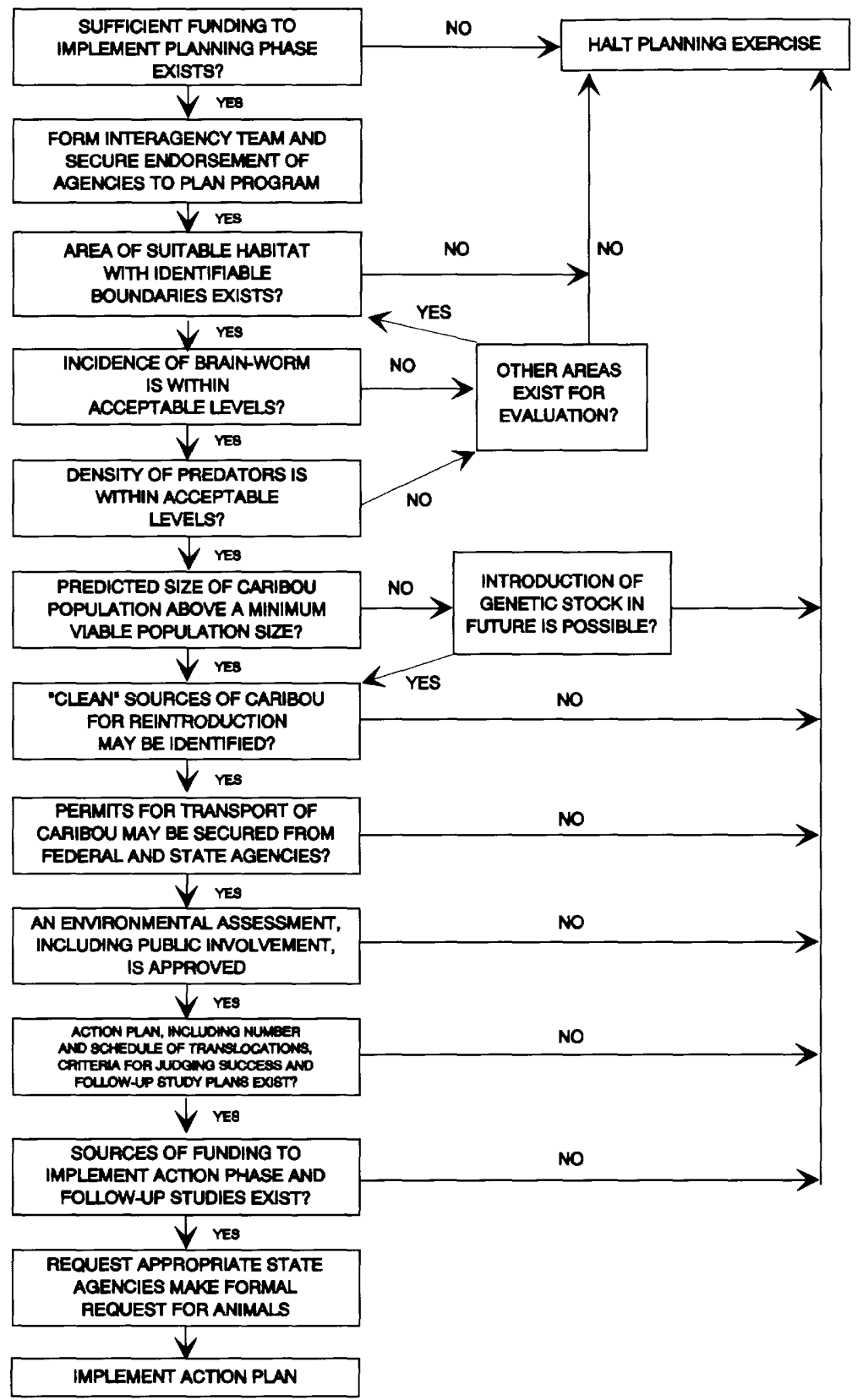

Fig. 9.2. Flow chart for assessing the feasibility of restoring woodland caribou to the Lake Superior region (Gogan et al. 1990). 
Pavlovic, Chapter 7, McEachern et al., Chapter 8, this volume). A metapopulation consists of a constellation of small populations that interact loosely, but experience environmental impacts independently, and have differential probabilities of dispersal, establishment, growth, and extinction. Managing several small populations as a metapopulation could involve providing corridors for the natural dispersal of individuals among populations, direct relocation, and including captive individuals at zoological parks as a population (Gogan 1990).

Because several small populations of woodland caribou have persisted along the north shore of Lake Superior, it might appear that small populations are viable. These herds, however, have been isolated for only 15-30 years, and in the last 15 years stray bulls have moved between some north shore herds (Bergerud 1985, 1989; Darby et al. 1989). The prognosis for most of the existing Lake Superior herds is actually bleak. Bergerud (1989), for example, predicted a high probability of extinction for the Pukaskwa National Park herd within 25 years. Food resources are greatly depleted on Pic Island (Ferguson et al. 1988) and the Slate Islands (A.T. Bergerud, personal communication). Fluctuations in the size of the Slate Islands herd, characterized by periodic widespread starvation, have been increasing in amplitude recently (A.T. Bergerud, personal communication), suggesting that total population collapse is likely despite a mean population size of 250-400 animals. It seems likely that historic Lake Superior populations (including Isle Royale) were part of a regional metapopulation, with regular gene flow and ready recolonization of islands from the mainland.

\section{VORTEX population extinction modeling}

Using the population extinction model VORTEX (Lacy 1991), various restoration scenarios were examined for Isle Royale National Park, Michigan. Focusing these simulations on Isle Royale highlights the isolation of woodland caribou at any of the release sites under consideration in the western Lake Superior region. The VORTEX model uses Monte Carlo simulations of demographic events, environmental variation, and catastrophes to calculate persistence times for numerous release scenarios, permitting predictions of how long populations established by different restoration schemes would survive. It is possible to estimate how many animals would have to be released over how many years, and with what frequency reinforcements would have to be released, to sustain a population for a given number of years. For the woodland caribou, the number of animals released, number of years of releases, mortality rates, and carrying capacities were varied between simulation runs. 
Table 9.2. Simulated population persistence times (in years) of selected release scenarios for woodland caribou released to Isle Royale by use of program VORTEX (Cochrane 1991).

\begin{tabular}{|c|c|c|c|c|c|}
\hline \multirow[b]{2}{*}{$K$} & \multirow{2}{*}{$\begin{array}{l}\text { Mortality } \\
\text { Rate }\end{array}$} & \multicolumn{4}{|c|}{ Percent of populations surviving } \\
\hline & & 90 & 50 & 10 & 0 \\
\hline 54 & moderate & 63 & 79 & 93 & $>100$ \\
\hline 54 & high & 31 & 44 & 55 & 70 \\
\hline 27 & high & 21 & 31 & 39 & 50 \\
\hline
\end{tabular}

In preliminary simulations, high carrying capacities were used (so that population size was not immediately truncated below the number of animals initially released). Persistence times were not improved by releasing more than about 75 animals or by extending the release time over more than one year (not accounting for logistical complications). Subsequent simulations with lower, more realistic carrying capacities were reduced to three basic variants (Table 9.2). The model found that a translocated caribou population with fewer than 54 animals and suffering high mortality would not survive for 50 years (mean time to extinction was 31 or 44 years). With less severe mortality and an average population size of 54 animals, mean persistence times would increase to 79 years. Unfortunately, the VORTEX program could not satisfactorily model two release options that might have been shown to overcome the initial effects of high wolf predation; 1) 'swamping' the release site with woodland caribou (in excess of long-term carrying capacity), and 2) releasing woodland caribou while wolves are absent and subsequently restoring wolves (i.e. allowing wolf predation rates to increase gradually).

Models of woodland caribou restoration strategies were developed previously as part of the Maine woodland caribou reintroduction plan (McCollough 1987). A stochastic model based on that of Grier (1980) was used to evaluate six release options for three projected levels of herd survival and fecundity. The Maine simulation predicted only short-term probabilities of achieving the approximately 100 animals believed necessary for long-term viability (M. McCollough, personal communication). The results revealed that only restorations that had initial high survivorship and intermediate or high fecundity exceeded 100 animals after 10 years. A total of 98 to 115 animals released over five years (with adult sex ratios heavily skewed towards females) performed better than fewer than 75 animals released over three years. Initial survival rate had a greater effect on success than did fecundity, especially when the animals released were yearlings. 
In the actual two years of releases of woodland caribou to the Baxter State Park region in Maine, mortality far exceeded that of the models, principally because of black bear predation and diseases carried from captivity (McCollough \& Connery 1991). Based on this experience, the advisory committee of the Maine project concluded that three releases of more than 100 animals would be necessary to overcome the initial high mortality rates and establish a core herd of animals acclimatized to the new habitat.

\section{Evaluation of potential restoration sites}

Since 1988, the North Central Caribou Corporation has been evaluating three sites for potential woodland caribou restoration. The $4450 \mathrm{~km}^{2}$ Boundary Waters Canoe Area Wilderness (BWCAW), Superior National Forest, Minnesota, and the adjacent $4790 \mathrm{~km}^{2}$ Quetico Provincial Park, Ontario, compose the largest potential area for restoration. Voyageurs National Park, Minnesota, has the next largest area available $\left(880 \mathrm{~km}^{2}\right)$. Both of these are mainland sites. The last site, the $545 \mathrm{~km}^{2}$ Isle Royale National Park, Michigan, is an island $24 \mathrm{~km}$ south of the north shore of Lake Superior. A summary of site characteristics can be found in Table 9.3.

\section{BWCAW/Quetico Provincial Park}

A previous restoration plan (Karns 1980) identified a $520 \mathrm{~km}^{2}$ area southwest of Little Saganagana Lake within the BWCAW as the most suitable habitat in Minnesota for woodland caribou. The Natural Resources Research Institute, University of Minnesota, Duluth, is determining the extent of year-round habitat for woodland caribou in this region by classifying a satellite image of the BWCAW according to important woodland caribou habitat attributes on a geographical information system (GIS), using US Forest Service stand compartment maps, aerial photography, and ground verification (M. Broschart \& J. Pastor, personal communication). Preliminary analyses suggest that an area of suitable habitat extends across the international boundary into Quetico Provincial Park.

The summer distribution of white-tailed deer around the Little Saganagana Lake region is the outer boundary of the area that might be reasonably expected to support woodland caribou. The reported incidence of meningeal brainworm in white-tailed deer in this region ranges from less than $10 \%$ to greater than $90 \%$ (Lankester \& Anderson 1968). Long-term studies of whitetailed deer in northern Minnesota show that the population concentrates at winter yards away from the proposed Little Saganagana Lake release site. The frequency of meningeal brainworm larvae in pellet groups of wintering white- 
Table 9.3. Evaluation of factors considered critical to success of woodland caribou restoration at three sites in the Western Lake Superior Region

\begin{tabular}{|c|c|c|c|c|c|}
\hline \multirow[t]{2}{*}{ Site } & \multirow{2}{*}{$\begin{array}{l}\text { Habitat } \\
\text { quality }\end{array}$} & \multicolumn{2}{|c|}{ Predators } & \multicolumn{2}{|c|}{ White-tailed deer } \\
\hline & & $\begin{array}{l}\text { wolves per } \\
1000 \mathrm{~km}^{2}\end{array}$ & black bears & density & $\begin{array}{c}\text { incidence of } \\
\text { brainworm } \\
(\%)\end{array}$ \\
\hline $\begin{array}{l}\text { Little Saganagana } \\
\text { Lake, BWCAW }\end{array}$ & $\begin{array}{c}\text { Evaluation } \\
\text { pending }\end{array}$ & 15 & $\begin{array}{c}\text { Evaluation } \\
\text { underway }\end{array}$ & Low & $44-60$ \\
\hline Voyageurs N.P. & $\begin{array}{c}\text { Evaluation } \\
\text { pending }\end{array}$ & 30 & Common & High & $>90$ \\
\hline Isle Royale N.P. & $\begin{array}{c}\text { Evaluation } \\
\text { pending }\end{array}$ & 20 & Absent & Absent & - \\
\hline
\end{tabular}

tailed deer in these yards in 1989 ranged between 44 and 60\% (Jordan \& Pitt 1989). In summer, most white-tailed deer range about $26 \mathrm{~km}$ from these winter yards (M.E. Nelson, personal communication). Thus, although the Little Saganagana Lake area is beyond the range of most white-tailed deer using the nearest wintering yards, low densities of white-tailed deer may be expected to be present in summer. These low densities of white-tailed deer are reflected in two surveys for the presence of meningeal brainworm. A survey around Little Saganagana Lake in 1977 found an incidence of 5\% (Karns 1980). A summer 1989 survey of a $130 \mathrm{~km}^{2}$ area around Little Saganagana Lake found none of the intermediate host gastropod snails, and only one of four deer pellet groups located contained meningeal brainworm larvae (Jordan \& Pitt 1989).

Wolf densities in the BWCAW average 15 per $1000 \mathrm{~km}^{2}$ (M.E. Nelson, personal communication), half again the maximum density that woodland caribou can tolerate without secure escape habitat (Bergerud \& Mercer 1989).

A deer-free area of $6500 \mathrm{~km}^{2}$ in the BWCAW and Quetico Provincial Park should support between 40 and 130 woodland caribou, providing adequate predator escape cover is available. Such a population may persist for many generations, but will not persist indefinitely in isolation from other populations.

\section{Voyageurs National Park}

Voyageurs National Park has contracted for Habitat Evaluation Procedures (HEP) (US Fish and Wildlife Service 1981) to be used to develop a Habitat Suitability Index (HSI) Model for woodland caribou, which will be applied to the Park and adjacent lands. The HSI model will summarize existing knowledge of woodland caribou habitat requirements and identify those components that are most likely to limit the growth of a restored woodland caribou popula- 
tion. Preliminary habitat analysis suggests that currently Voyageurs National Park would not provide year-round habitat for woodland caribou.

There are currently 30 wolves per $1000 \mathrm{~km}^{2}$ at Voyageurs National Park (P. J. P. Gogan, unpublished data), more than three times the maximum density that woodland caribou can tolerate without secure escape habitat (Bergerud \& Mercer 1989). Actual densities of black bears are unknown, but they are quite common, and are often seen swimming between islands in the park's larger lakes.

White-tailed deer densities at Voyageurs National Park may reach 19 per $\mathrm{km}^{2}$, and the incidence of meningeal brainworm larvae in white-tailed deer fecal samples and mature parasites in the crania of white-tailed deer dying of natural causes exceeds $90 \%$ (P. J. P. Gogan, unpublished data).

According to the overall density estimate of 0.05 per $\mathrm{km}^{2}$ for woodland caribou at the inland site at Lake Nipigon (Bergerud et al. 1990), the $880 \mathrm{~km}^{2}$ of land and waters within Voyageurs should under favorable conditions support approximately 45 woodland caribou. However, because of the high densities of predators and white-tailed deer infected with meningeal brainworm, current conditions are far from favorable.

\section{Isle Royale National Park}

Plans call for habitat conditions at Isle Royale National Park to be assessed by modifying the HSI model being developed for Voyageurs National Park. The model will be adjusted for the absence of black bear, white-tailed deer and meningeal brainworm. The presence and configuration of offshore islets adjacent to Isle Royale will weigh heavily in the assessment of escape habitat suitability.

The wolf population on Isle Royale has declined to 12 from a high of 50 in 1980 (Peterson 1991). The population is expected to remain low in the foreseeable future, and has a high probability of declining to extirpation owing to inbreeding and reproductive failure (R. O. Peterson, personal communication). Hence, densities should remain below 20 per $1000 \mathrm{~km}^{2}$ for several years. Still, this density is twice that identified as likely to allow restoration of woodland caribou without substantial escape habitat (Bergerud \& Mercer 1989).

Although white-tailed deer were introduced to Isle Royale in 1910, they died out by no later than 1936 (Holte \& Holte 1965). There is no evidence of meningeal brainworm in moose at Isle Royale. A report of meningeal brainworm larvae in Isle Royale moose feces (Karns \& Jordan 1969) was based on a misidentification (Lankester \& Hauta 1989). Whether or not reintroduced woodland caribou will infect the Isle Royale moose with parasites or pathogens must be determined. 
In the short term, a small release (12-24 animals) of woodland caribou to Isle Royale might be sufficient to establish a nuclear herd, given adequate winter escape habitat. A. T. Bergerud (personal communication) predicts that 20-25 woodland caribou could survive on Isle Royale by using other islands to escape from wolf predation. Initially, population growth would be good. But as the herd grew, it would be subject to increasing mortality rates $(10-20 \%$ or higher annual adult mortality) and, with six or more wolves, the population probably could not exceed an average density of 0.1 per $\mathrm{km}^{2}$ (a carrying capacity of 54). Under these conditions, the VORTEX model predicts that, without supplementation, the woodland caribou population would not survive beyond a few years even if 75 animals were released over three years (VORTEX incorporates a density-dependent reduction in reproduction and survival when carrying capacity is exceeded).

Thus, in the long term, caribou could not persist at Isle Royale without management intervention, such as 'artificial immigration' of breeding males through periodic translocations. VORTEX modeling, and evidence from Pukaskwa National Park and elsewhere (Klein 1968), indicates that mature males disappear first from declining, small populations, owing to disproportionately high mortality and dispersal rates. The current Isle Royale wolf decline and restoration debate (wolf numbers on Isle Royale are unlikely to ever reach a long-term (more than 100-year) MVP and the population will probably need management intervention to persist) foreshadows this dilemma.

\section{Conclusions}

Small numbers of ungulates translocated into favorable habitats have frequently grown into large populations (Griffith et al. 1989). In discussing the potential of restoring woodland caribou to the Lake Superior region, numerous biologists pointed out that woodland caribou herds have prospered from initial transplants of fewer than 20 animals. Griffith et al. (1989) found that for native game species, 20-40 founding animals was sufficient for high translocation success. However, success was defined vaguely as a 'self-sustaining population,' and no time frame was provided. Soulé (1986) points out that 'viability' has traditionally been equated with short-term persistence in a constant environment, or 'resilience'. MVP estimates rise dramatically, and call for larger founding populations, when they take into account long-term threats such as epidemics, catastrophes, and genetic drift.

It is difficult to restore woodland caribou to mainland sites (Bergerud \& Mercer 1989), and of the three restoration sites that the North Central Caribou 
Corporation is currently evaluating, Isle Royale is the only island. However, it has a relatively high density of wolves and limited escape cover, and can support only a relatively small number of woodland caribou. Yet, in some ways, Isle Royale offers the best scenario for woodland caribou restoration in the Lake Superior region, because it is free of white-tailed deer and meningeal brainworm, it is free of black bears, and reintroduced woodland caribou are unlikely to disperse to the mainland.

Nevertheless, the release of a reasonably achievable number of woodland caribou (e.g. 100) on Isle Royale would not result in an independently viable population, or in any population at all, without follow-up releases within 10 years. Based on MVP theory assuming high mortality rates, high variance in mortality, and a carrying capacity of no more than 54 animals, this is not surprising.

Woodland caribou translocated to the BWCAW/Quetico Provincial Park area would be exposed to mortality agents, such as black bear predation and meningeal brainworm, not present at Isle Royale. However, the site has more land, and a correspondingly larger herd with a greater probability of long-term persistence could be established. The total area of potentially suitable habitat and barriers to dispersal into deer-free areas require further delineation.

The limited number of woodland caribou that Voyageurs National Park can support, plus its high densities of predators and of white-tailed deer with a high incidence of meningeal brainworm, render it the least favorable of the three restoration sites under consideration.

VORTEX modeling indicates that any herd reintroduced within the constraints imposed by the western Lake Superior region will not achieve longterm population viability. It is possible, however, that one or more herds could be restored to this region and, with management, developed into a part of a larger metapopulation.

\section{Acknowledgements}

Numerous people aided in our assessment of the potential of restoring woodland caribou by discussing and sharing information on caribou biology, translocation, and the region's natural resources. We are grateful to Gordon Eason, Wawa District, Ontario Ministry of Natural Resources, for providing information on recent translocations of woodland caribou to the eastern end of Lake Superior and reviewing earlier drafts of this manuscript. We are also grateful to Terry Kreeger and his students at the University of Minnesota for the numerous runs of program VORTEX. Financial support was provided to one of us (JFC) by the North Central Caribou Corporation and the Natural 
Heritage Program of the Michigan Department of Natural Resources. We are grateful to NCCC president Jim Nelson, and other members of NCCC and its advisory committee, for their continued efforts to reestablish woodland caribou in the border region.

\section{Literature cited}

Abraham, K., Darby, B., Day, Q., Foster, B., McNicol, J., Racey, G. \& Timmermann, T. (1990) Timber management guidelines for the provision of woodland caribou habitat. Report to Ontario Ministry of Natural Resources. Thunder Bay, Ontario Ministry of Natural Resources.

Aldous, C. M. (1931) A report of the investigations of reindeer grazing in the Superior National Forest. Washington, D.C.: Division of Investigations, US Biological Survey.

Anderson, R. C. (1971) Neurological disease in reindeer (Rangifer tarandus tarandus) introduced into Ontario. Canadian Journal of Zoology, 49, 159-66.

Anderson, R. C. \& Prestwood, A. K. (1981) Lungworms. In Diseases and parasites of White-Tailed Deer, ed. Davison, W. R., Hayes, F. A., Nettles, V. F., \& Kellog, F. E., pp. 266-317. Miscellaneous Publication 7. Tall Timbers Research Station.

Anderson, R. C., \& Strelive, U. R. (1968) The experimental transmission of Pneumostrongylus tenuis to caribou (Rangifertarandus terranovae). Canadian Journal of Zoology, 46, 503-10.

Baker, R. H. (1983) Michigan Mammals. East Lansing: Michigan State University Press.

Bergerud, A. T. (1971) The population dynamics of Newfoundland caribou. Wildlife Monographs, 25, 1-55.

Bergerud, A. T. (1972) Food habits of Newfoundland caribou. Journal of Wildlife Management, 36, 913-23.

Bergerud, A. T. (1974) Decline of caribou in North America following settlement. Journal of Wildlife Management, 38, 757-70.

Bergerud, A. T. (1978) Caribou. In Big Game of North America, Ecology and Management, ed. Schmidt, J. L. \& Gilbert, D. L., pp. 83-101. Harrisburg: Stackpole Books.

Bergerud, A. T. (1980) A review of the population dynamics of caribou and wild reindeer in North America. In Proceedings of the Second International Reindeer/Caribou Symposium, ed. Reimers, E., Gaare, E. \& Skenneberg, S. pp. 556-81. Direktoratet for vilt og ferkvannsfisk. Trondheim, Norway.

Bergerud, A. T. (1983) The natural population control of caribou. In Symposium on Natural Regulation of Wildlife Populations (1978), ed. Bunnell, F. L., Eastman, D. S. \& Peek, J. M., pp. 14-61. Moscow: Forest, Wildlife and Range Experiment Station.

Bergerud, A. T. (1985) Antipredator strategies of caribou, dispersion along shorelines. Canadian Journal of Zoology, 63, 1324-29.

Bergerud, A. T. (1988) Caribou, wolves and man. Trends in Ecology and Evolution, 3, $68-72$.

Bergerud, A. T. (1989) The abundance, distribution and behaviour of caribou in Pukaskwa National Park, 1972-1988. Bergerud and Associates Contract Report \#88-CPS-PUK, Scientific Review of Caribou Management Activities in Pukaskwa National Park. Fulford Harbour. 
Bergerud, A. T., Butler, H. E., \& Miller, D. R. (1984) Anti-predator tactics of calving caribou, dispersion in mountains. Canadian Journal of Zoology, 62, 1566-75.

Bergerud, A. T. \& Elliot, J. P. (1986) Dynamics of caribou and wolves in northern British Columbia. Canadian Journal of Zoology, 64, 1515-29.

Bergerud, A. T., Ferguson, R. \& Butler, H. E. (1990) Spring migration and dispersion of woodland caribou at calving. Animal Behavior, 39, 360-8.

Bergerud, A. T. \& Mercer, W. E. (1989) Caribou introductions in eastern North America. Wildlife Society Bulletin, 17, 111-20.

Bergerud, A. T. \& Page, R. E. (1987) Displacement and dispersion of parturient caribou at calving as antipredator tactics. Canadian Journal of Zoology, 65, 1597-606.

Bonefant, C. (1974) Resurgence of the caribou in Quebec. Canadian Geographic, 92, $48-56$.

Cochrane, J. F. (1991) Feasibility study for the restoration of woodland caribou at Isle Royale National Park. Resources Management Report. Houghton: Isle Royale National Park.

Cringan, A. T. (1957) History, food habits and range requirements of the woodland caribou of continental North America. Transactions of the North American Wildlife Conference, 22, 485-501.

Cumming, H. G. \& Beange, D. B. (1987) Dispersion and movements of woodland caribou near Lake Nipigon, Ontario. Journal of Wildlife Management, 51, 69-78.

Darby, W. R. \& Pruitt, W. O. Jr. (1984) Habitat use, movements and grouping behavior of woodland caribou, Rangifer tarandus caribou, in southeastern Manitoba. Canadian Field-Naturalist, 98, 184-90.

Darby, W. R., Timmermann, H. R., Snider, J. B., Abraham, K. F., Stefanski, R. A. \& Johnson, C. A. (1989) Woodland Caribou in Ontario, Background to Policy. Toronto: Ontario Ministry of Natural Resources.

Dymond, J. R., Snyder, L. L. \& Logier, E. B. S. (1928) A faunal survey of the Lake Nipigon region, Ontario. Transactions of the Royal Canadian Institute, 16, 233-91. (Reprinted as Contribution no. 1, Royal Ontario Museum of Zoology.)

Edmonds, E. J. (1986) Woodland caribou, their status and distribution in Alberta. Alberta Naturalist, 16, 73-8.

Edmonds, E. J. (1988) Population status, distribution, and movements of woodland caribou in west central Alberta. Canadian Journal of Zoology, 66, 817-826.

Edmonds, E. J. \& Bloomfield, M. (1984) A study of woodland caribou (Rangifer tarandus caribou) in west central Alberta, 1979 to 1983. Edmonton: Alberta Energy and Natural Resources, Fish and Wildlife Division. 203 pp.

Euler, D. L., Snyder, B. \& Timmermann, H. R. (1976) Woodland caribou and plant communities on the Slate Islands, Lake Superior. Canadian Field-Naturalist, 90, $17-21$.

Fashingbauer, B. A. (1965) The caribou in Minnesota. In Big Game in Minnesota, ed. J.B. Moyle, pp. 136-166. Technical Bulletin 9. St. Paul: Minnesota Department of Conservation.

Ferguson, S. H., Bergerud, A. T. \& Ferguson, R. (1988) Predation risk and habitat selection in the persistence of a remnant caribou population. Oecologia, 76, $236-45$.

Fuller, T. K. \& Keith, L. B. (1981) Woodland caribou population dynamics in northeastern Alberta. Journal of Wildlife Management, 45, 197-211.

Gilpin, M. E. \& Soulé, M. E. (1986) Minimum viable populations, processes of species extinction. In Conservation Biology, the Science of Scarcity and Diversity, ed. Soulé, M.E., pp. 19-34. Sunderland: Sinauer Associates.

Gogan, P. J. P. (1990) Considerations in the reintroduction of native mammalian 
species to restore natural ecosystems. Natural Areas Journal, 10, 210-7.

Gogan, P. J. P., Jordan, P. A. \& Nelson J. L. (1990) Planning to reintroduce woodland caribou to Minnesota. Transactions of the North American Wildlife and Natural Resources Conference, 55, 599-608.

Gray, J. B. \& Samuel, W. M. (1986) Parelaphostrongylus odocoilei (Nematoda: Protostrongylidae) and a protostrongylid nematode in woodland caribou (Rangifer tarandus caribou) of Alberta, Canada. Journal of Wildlife Diseases, 22, 48-50.

Grier, J. (1980) Ecology, A simulation model for small populations of animals. Creative Computing, 6, 116-21.

Griffith, B., Scott, J. M., Carpenter, J. W. \& Reed, C. (1989) Translocation as a species management tool: Status and strategy. Science, 245, 477-80.

Holte, I. \& Holte, E. (1965) Interview with L. Rakeestraw 9/10/65, Wright Island, Isle Royale, Michigan. Isle Royale National Park Oral History No. 2. Isle Royale National Park: Michigan Department of Natural Resources.

Jakimchuk, R. D., Ferguson, S. H. \& Sopuck, L. G. (1987) Differential habitat use and sexual segregation in the central arctic caribou herd. Canadian Journal of Zoology, 65, 534-41.

Jordan, P. A. \& Pitt, W. C. (1989) A survey for Parelaphostrongylus tenuis in the proposed caribou reintroduction site Little Saganagana area of the BWCAW, Minnesota. Report by the North Central Caribou Corporation. Duluth: North Central Caribou Corporation.

Karns, P. D. (1980) Environmental analysis report. Reintroduction of woodland caribou, Superior National Forest. Report prepared for the United States Forest Service. Duluth: United States Department of Agriculture.

Karns, P. D. \& Jordan, P. A. (1969) Pneumostrongylus tenuis in moose on a deer-free island. Journal of Wildlife Management, 33, 431-3.

Klein, D. R. (1968) The introduction, increase, and crash of reindeer on St. Matthew Island. Journal of Wildlife Management, 32, 350-67.

Lacy, R. (1991) VORTEX, Simulation model of stochastic population change. Version 8.0. Brookfield: Chicago Zoological Park.

Lande, R. \& Barrowclough, G. F. (1987) Effective population size, genetic variation and their use in population management. In Viable populations for conservation, ed. Soulé, M. E., pp. 85-123. Cambridge: Cambridge University Press.

Lankester, M. W. (1976) A Protostrongylid nematode of woodland caribou and implications in moose management. North American Moose Conference and Workshop, 12, 173-90.

Lankester, M. W. \& Anderson, R. C. (1968) Gastropods as intermediate hosts of meningeal worm, Pneumostrongylus tenuis Dougherty. Canadian Journal of Zoology, 46, 373-383.

Lankester, M. W., Crichton, V. J. \& Timmermann, H. R. (1976) A protostrongylid nematode (Strongylida, protostrongylidae) in woodland caribou (Rangifer tarandus caribou). Canadian Journal of Zoology, 57, 1384-92.

Lankester, M. W. \& Hauta, P. L. (1989) Parelaphostrongylus andersoni (Nematoda, Protostrongylidae) in caribou (Rangifer tarandus) of northern and central Canada. Canadian Journal of Zoology, 67, 1966-75.

Lankester, M. W. \& Northcott, T. H. (1979) Elaphostrongylus cervi Cameron 1931 (Nematoda, Metastrongyloidea) in caribou (Rangifer tarandus caribou) in Newfoundland. Canadian Journal of Zoology, 57, 1384-92.

McCollough, M. (1987) A management and research plan for the reintroduction of woodland caribou to Maine. Maine Caribou Project. Orono: University of Maine. 
McCollough, M. \& Connery, B. (1991) An attempt to reintroduce woodland caribou to Maine 1986-1990. Final Report. Maine Caribou Project, 1986-1990. Orono: University of Maine.

Mech, L. D., Nelson, M. E. \& Drabik, H. F. (1982) Reoccurrence of caribou in Minnesota. American Midland Naturalist, 108, 206-8.

Nudds, T. D. (1990) Retroductive logic in retrospect: the ecological effects of meningeal worms. Journal of Wildlife Management, 54, 396-402.

Ontario Ministry of Natural Resources. (1986) Slate Islands Provincial Park Management Plan; Preliminary Draft. Terrace Bay: Ontario Ministry of Natural Resources.

Ontario Ministry of Natural Resources. (1988) Quetico Provincial Park Management Plan. 1988 Policy Review. Toronto: The Queen's Printer.

Peterson, R. O. (1991) Ecological studies of wolves on Isle Royale; Annual Report 1990-1991. Houghton: Isle Royale Natural History Association.

Peterson, W. J. (1981) Coming of the caribou. Minnesota Volunteer, 44, 17-23.

Pybus, M. J. \& Samuel, W. M. (1984) Parelaphostrongylus andersoni (Nematoda: Protostrongylidae) and P. odocolei in two cervid definitive hosts. Journal of Parasitology, 70, 507-15.

Riis, P. B. (1938a) Woodland caribou and time. Parks and Recreation, 21, 529-35.

Riis, P. B. (1938b) Woodland caribou and time. Parks and Recreation, 21, 594-600.

Riis, P. B. (1938c) Woodland caribou and time. Parks and Recreation, 21, 639-45.

Riis, P. B. (1938d) Woodland caribou and time. Parks and Recreation, 22, 23-30.

Schaefer, J. A. \& Pruitt, W. O. (1991) Fire and woodland caribou in southeastern Manitoba. Wildlife Monograph, 116, 1-39.

Servheen, G. (1988) Selkirk Mountains caribou transplant: October 1987 September 1988. Boise: Idaho Department of Fish and Game.

Servheen, G. (1989) Selkirk Mountains caribou transplant: October 1988 September 1989. Boise: Idaho Department of Fish and Game.

Shoesmith, M. (1986) Woodland caribou in Manitoba. Provincial Museum of Alberta Natural History Occasional Paper, 9, 311-13.

Shoesmith, M. W. \& Storey, D. R. (1977) Movements and associated behaviour of woodland caribou in central Manitoba. Proceedings of the International Congress of Game Biologists, 13, 51-64.

Simkin, D. W. (1965) A preliminary report of the woodland caribou study in Ontario. Section Report (Wildlife) No. 59, Toronto: Ontario Department of Lands and Forests.

Skoog, R. O. (1968) Ecology of the caribou in Alaska. Ph. D. dissertation, Berkeley: University of California.

Soulé, M. E. (1986) Conservation biology and the real world. In Conservation Biology: the Science of Scarcity and Diversity, ed. Soulé, M. E., pp. 1-12. Sunderland: Sinauer Associates.

Soulé, M. E. (1987) Introduction. In Viable Populations for Conservation, ed. Soulé, M. E., pp. 1-10. Cambridge University Press.

Stevenson, S. K. \& Hatler, D. F. (1985) Woodland caribou and their habitat in southern and central British Columbia. Report Number 23. Victoria: British Columbia Ministry of Forest Land Management.

Thomas, D. C., Barry, S. J. \& Kiliaan, H. P. (1989) Fetal sex ratios in caribou: maternal age and condition effects. Journal of Wildlife Management, 53, $885-90$.

US Fish \& Wildlife Service. (1981) Standards for the development of habitat suitability index models. 103 ESM. Washington, D. C.: US Fish and Wildlife Service, Division of Ecological Services. 